\title{
GCU
}

Glasgow Caledonian

University

University for the Common Good

\section{Enhanced condition monitoring of power transformers through improvement in accuracy of DGA interpretation}

Aburaghiega, Ehnaish; Farrag, Mohamed Emad; Hepburn, Donald; Garcia, Belen

Published in:

51st International Universities Power Engineering Conference (UPEC)

DOI:

10.1109/UPEC.2016.8114060

Publication date:

2017

Document Version

Author accepted manuscript

Link to publication in ResearchOnline

Citation for published version (Harvard):

Aburaghiega, E, Farrag, ME, Hepburn, D \& Garcia, B 2017, Enhanced condition monitoring of power

transformers through improvement in accuracy of DGA interpretation. in 51st International Universities Power Engineering Conference (UPEC). IEEE, pp. 1-6. https://doi.org/10.1109/UPEC.2016.8114060

\section{General rights}

Copyright and moral rights for the publications made accessible in the public portal are retained by the authors and/or other copyright owners and it is a condition of accessing publications that users recognise and abide by the legal requirements associated with these rights.

Take down policy

If you believe that this document breaches copyright please view our takedown policy at https://edshare.gcu.ac.uk/id/eprint/5179 for details

of how to contact us. 


\section{Enhanced Condition Monitoring of Power Transformers through Improvement in Accuracy of DGA Interpretation}

\author{
Ehnaish Aburaghiega \\ Glasgow Caledonian University \\ UK \\ Ehnaish.Aburaghiega@gcu.ac.uk \\ Dr. Mohamed Emad Farrag \\ Glasgow Caledonian University \\ UK \\ Mohamed.Farrag@gcu.ac.uk
}

\author{
Dr. Donald M Hepburn \\ Glasgow Caledonian University \\ UK \\ D.M.Hepburn@gcu.ac.uk
}

\author{
Dr. Belen Garcia \\ Universidad Carlos III de \\ Madrid, Spain \\ bgarciad@ing.uc3m.es
}

\begin{abstract}
Transformer failure in electricity supply grids has a high financial impact, due to failure to meet commercial contract and possibility of transformer replacement cost. Therefore, detecting fault inception is very important in order to keep the transformer operating with recommended efficiency, hence ensuring stability of the electric network. Dissolved gas analysis (DGA) of a transformer can provide clear indication of thermal and electrical stresses on power transformer insulation and is considered as one of the most effective tools for oil-filled power transformer diagnostics. DGA is used to detect incipient faults in order to manage the fault severity. Both on-line and offline condition monitoring methods can be applied to obtain gas content, thereafter there are many interpretation techniques for DGA results. The accuracy of these techniques is dependent on the operator's experience and knowledge of the materials and equipment involved. In this work, a combined fuzzy logic analysis technique for monitoring of power transformers based on DGA analysis is proposed, the system uses the 7 key gases to diagnose the health of the transformer and, where applicable, fault type. Initially, gas levels are considered using the IEEE standard as a basis to indicate the health of the transformer. A combined fuzzified analytical tool, based on Duval Triangle, Doernenburg ratio and Key gas method, are analysed to identify the fault type, improving on the accuracy of the individual interpretation techniques. The analytical tool has been applied to 444 sample faults reported in the literature to assess the accuracy of the proposed system. Results presented show the system's overall decision has improved capability of identifying the transformer condition over individual methods. The proposed system is proved to have $99 \%$ accuracy in identifying the transformer normality. For cases where transformers were faulty, the approach has $98.76 \%$ accuracy in recognising the actual fault, superior to individual approaches.
\end{abstract}

Index Terms-Power Transformer monitoring, DGA, Duval triangle, Doernenburg ratio, Key gas

\section{INTRODUCTION}

In some cases transformer failures may lead to a complete outage of the network and, due to oil leakage, environmental hazard. A major concern of companies is, therefore, preventing transformer failures though improving the monitoring and diagnosis of faults, in order to reduce unexpected transformer failure [1]. Electrical, thermal, and mechanical stresses decrease the quality of transformer insulation and increase the possibility of faults occurring. Online condition monitoring of power transformers has been successfully applied to meet operation challenges and used to extend the transformer life cycle [2]. Mineral oil is used as the liquid insulation in the majority of power transformers, due to its excellent properties, availability and low cost.
Mineral oil acts effectively as coolant and electric insulation between the transformer elements under different operating conditions [3]. However, the majority of the transformers in service have been installed and operating under different environmental and load condition for significant periods and the electrical and mechanical stresses lead to degradation and decomposition of the insulating material [4], [5], [6], [7]. Therefore, monitoring and diagnosis of faults through DGA is essential for power transformers [8], [9]. In a faulty transformer different gases are generated, i.e. Hydrogen $\left(\mathrm{H}_{2}\right)$, Acetylene $\left(\mathrm{C}_{2} \mathrm{H}_{2}\right)$, Methane $\left(\mathrm{CH}_{4}\right)$, Ethane $\left(\mathrm{C}_{2} \mathrm{H}_{6}\right)$, Ethylene $\left(\mathrm{C}_{2} \mathrm{H}_{4}\right)$, Carbon monoxide (CO) and Carbon dioxide $\left(\mathrm{CO}_{2}\right)$ : the concentration of these gases depends on fault type and severity [10]. Analyzing the concentration of the 7 key gases based on different DGA interpretation techniques such as Key Gas, Roger gas ratio, Doernenburg ratio, IEC gas ratio and Duval Triangle can indicate the fault type [11]. The accuracy of the applied interpretation techniques varies and can be dependent on personal experience [12], [13].

\section{DGA INTERPRETATION TECHNIQUES}

DGA is the most popular tool for detecting faults in oil filled transformers and can be effective, though different techniques are used to interpret DGA data [14]. As different faults generate specific hydrocarbon gases due to different energies, fault identification can be obtained from analysis of 7 Key gases [15]. This work applies a combination of fuzzy logic algorithms to IEEE-C57.108 [16] and DGA interpretation methods to assess the health of a transformer and to improve the accuracy of the fault identification decision.

\section{A- Healthy state of the transformer}

IEEE C57.104 classifies Key gas concentrations into four "Conditions" when assessing if a transformer is in a normal or abnormal state and when classifying risk status. Table I shows the upper limits of the concentration levels for the 7 key gases, Total Dissolved Combustible Gases (TDCG) for Condition 1, i.e. the transformer is "Healthy". However, any individual gas or TDCG exceeding the level indicates the transformer is "Un-healthy", in such cases further investigation for the fault type is required.

TABLE I

7 KEY GAS AND TDCG CONCENTRATION LIMITS [16]

The specified Dissolved key gas concentration limits $\left[\mu \mathrm{l} / \mathrm{l}(\mathrm{ppm})^{\mathrm{a}}\right]$

\begin{tabular}{|c|c|c|c|c|c|c|c|}
$\mathrm{H}_{2}$ & $\mathrm{CH}_{4}$ & $\mathrm{C}_{2} \mathrm{H}_{2}$ & $\mathrm{C}_{2} \mathrm{H}_{4}$ & $\mathrm{C}_{2} \mathrm{H}_{6}$ & $\mathrm{CO}$ & $\mathrm{CO}_{2}$ & TDCG \\
\hline
\end{tabular}

\begin{tabular}{c|c|c|c|c|c|c|c}
$\mathrm{H}_{2}$ & $\mathrm{CH}_{4}$ & $\mathrm{C}_{2} \mathrm{H}_{2}$ & $\mathrm{C}_{2} \mathrm{H}_{4}$ & $\mathrm{C}_{2} \mathrm{H}_{6}$ & $\mathrm{CO}$ & $\mathrm{CO}_{2}$ & TDCG \\
\hline 100 & 120 & 1 & 50 & 65 & 350 & 2500 & 720
\end{tabular}




\section{B- Duval Triangle method}

Duval's method was developed using approximately 1000 DGA samples for transformers with known diagnosed faults [17], the method based on the percentage of the three gases $\left(\mathrm{CH}_{4}, \mathrm{C}_{2} \mathrm{H}_{4}\right.$ and $\mathrm{C}_{2} \mathrm{H}_{2}$ ) ratios [18]. Faults detected are: Partial Discharge (PD), Thermal Fault with low temperature $\left(\mathrm{T} 1<300^{\circ} \mathrm{C}\right)$, Thermal fault with medium temperature $\left(300^{\circ} \mathrm{C}<\mathrm{T} 2<700^{\circ} \mathrm{C}\right)$, Thermal fault with high temperature $\left(\mathrm{T} 3>700^{\circ} \mathrm{C}\right)$, Low energy discharge (D1), High energy discharge (D2) and Mix of both thermal and electrical faults (DT) [19].

\section{C- Doernenburg ratio}

Doernenburg ratio interpretation is based on the value of four ratios of gases, $\left(\mathrm{R} 1=\mathrm{CH}_{4} / \mathrm{H}_{2}\right),\left(\mathrm{R} 2=\mathrm{C}_{2} \mathrm{H}_{2} / \mathrm{C}_{2} \mathrm{H}_{4}\right),\left(\mathrm{R} 3=\mathrm{C}_{2} \mathrm{H}_{2}\right.$ $\left./ \mathrm{CH}_{4}\right)$ and $\left(\mathrm{R} 4=\mathrm{C}_{2} \mathrm{H}_{6} / \mathrm{C}_{2} \mathrm{H}_{2}\right)$ [20]. Three fault types are detected using this method [16], Thermal decomposition, Partial Discharge and Arcing fault. Table II shows Doernenburg ratio interpretation for dissolved gases in oil.

TABLE II

DOERNENBURG RATIO AND DIAGNOSIS [16]

\begin{tabular}{|c|c|c|c|c|}
\hline Fault & R1 & R2 & R3 & R4 \\
\hline Thermal decomposition & $>1.0$ & $<0.75$ & $<0.3$ & $>0.4$ \\
\hline Partial Discharge (PD) & $<0.1$ & Not significant & $<0.3$ & $>0.4$ \\
\hline Arcing fault & $>0.1$ to $<1.0$ & $>0.01$ to $<0.1$ & $>0.3$ & $<0.4$ \\
\hline
\end{tabular}

\section{D- Key gas method}

As indicated in [16], key gas concentrations are used to detect fault type: the percentage of each key gas indicates the fault type, e.g. high percentage of Hydrogen in an oil sample indicates a PD.

\section{PROPOSED MODEL}

Enhancement of condition monitoring of power transformers through the developed system is based on improving the accuracy of fault type identification through incorporation of different DGA interpretation techniques into one comprehensive model, as illustrated in the flow chart in Fig 1.

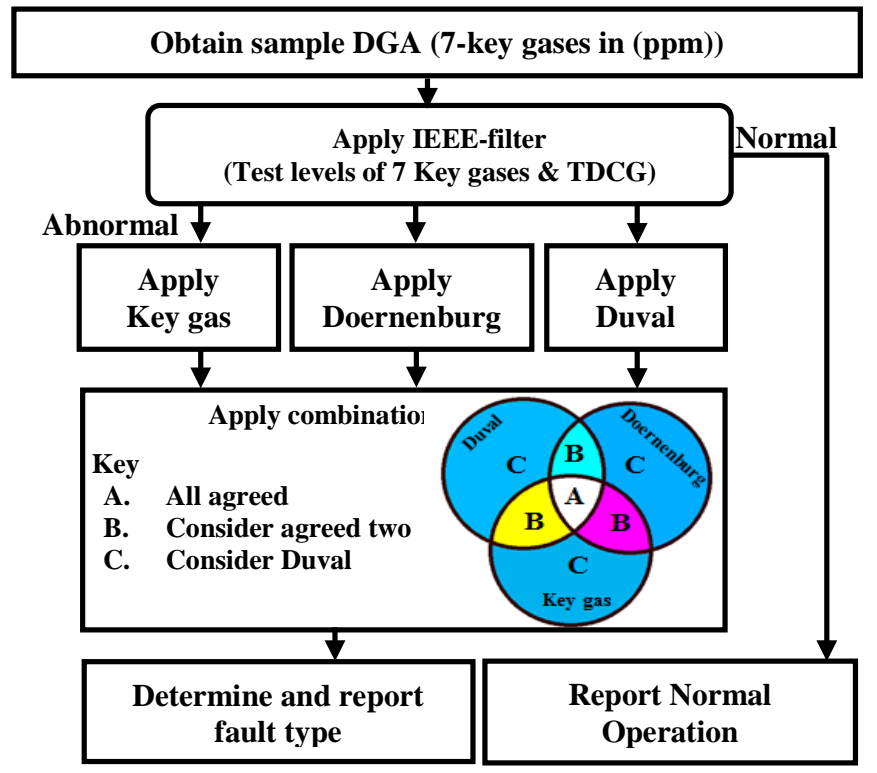

Fig.1: Flow chart of the proposed system
As can be seen, the system contains 5 different modules, IEEEfilter module is responsible for assessing the transformer health based on the concentration of the 7 key gases and TDCG. If the concentrations of the input parameters are below the concentration level specified in Table I, the transformer is considered as healthy and no additional test is required. If any individual gas or TDCG exceeds the specified satisfactory level, the transformer is considered as unhealthy and the three interpretation techniques are individually operated. A combination module is built based on using the outputs of the three interpretation techniques as variable inputs. Modules are discussed in detail in the fuzzification procedures.

\section{A- Overall decision of the model}

As discussed, the concentration level of the 7 gases are tested using IEEE-filter module, based on the limitation stated in Table I. IEEE-Filter's indication is used to determine whether to operate the three interpretation modules. For a healthy transformer, the interpretation techniques and the combination modules will remain off and the overall decision will be Normal Operation (NO). Otherwise, the three interpretation modules operate and three indications of fault type are obtained which is the input to the combination system module for a final decision on fault type. The overall decision of the system will be provided using variable codes that indicate normality or fault type for the transformer as demonstrated in Table III.

TABLE III

COMBINATION MODULE CODES AND DIAGNOSIS

COMBINATION MODULE CODES AND DIAGNOSIS
\begin{tabular}{|c|c|c|}
\hline Output code & Symbol & Indication \\
\hline 0 & NO & Normal operation \\
\hline 1 & PD & Partial Discharge \\
\hline 2 & T1 & Thermal Fault $\mathrm{T}<300^{\circ} \mathrm{C}$ \\
\hline 3 & T2 & Thermal Fault $300<\mathrm{T}<700^{\circ} \mathrm{C}$ \\
\hline 4 & T3 & Thermal Fault T $>700^{\circ} \mathrm{C}$ \\
\hline 5 & DT & Electrical and Thermal Fault \\
\hline 6 & D1 & Discharge of low energy \\
\hline 7 & D2 & Discharge of high energy \\
\hline 8 & TF & Thermal fault \\
\hline 9 & AF & Arcing fault \\
\hline
\end{tabular}

\section{FUZZY LOGIC MODULES}

The MATLAB fuzzy logic toolbox has been used to construct the system's modules, shown in Figures 2, 3 and 4. Each module is fuzzified into various sets of membership functions. Each interpretation technique has different sets of rules and each module was implemented individually and tested for accuracy. The system developed from the combined modules is used to improve the overall system accuracy. To demonstrate the working procedure of the system, the DGA analysis of set of data taken from [21] is described. The key gases concentrations for the item used and the reported fault are shown in Table IV.

TABLE IV

\begin{tabular}{|c|c|c|c|c|c|c|c|}
\hline $\mathrm{H}_{2}$ & $\mathrm{CH}_{4}$ & $\mathrm{C}_{2} \mathrm{H}_{2}$ & $\mathrm{C}_{2} \mathrm{H}_{4}$ & $\mathrm{C}_{2} \mathrm{H}_{6}$ & $\mathrm{CO}$ & $\mathrm{CO}_{2}$ & $\begin{array}{c}\text { Reported } \\
\text { Fault }\end{array}$ \\
\hline 60 & 10 & 4 & 4 & 4 & 780 & 7600 & (D1) \\
\hline
\end{tabular}




\section{A- IEEE-Filter fuzzy logic module}

According to [16] and based on the concentration limit in Table I, IEEE-Filter module has been fuzzfied, the module has a set of input membership function rules and output membership that provides the indication for the transformer under test. First the TDCG is calculated from 6 dissolved gases, thereafter all 7-key gases and TDCG are used as variable inputs: the concentration of each gas is checked against the related limit. The output codes for Normal and Abnormal condition are given in Table V.

For the tested transformer, the output code of the IEEEFilter module is "1", see Fig. 2: the transformer is unhealthy and further investigation is required to determine the fault type. The reason for this indication is that, as outlined in Fig. 2 , the concentration of $\mathrm{C}_{2} \mathrm{H}_{2}, \mathrm{CO}, \mathrm{CO}_{2}$ and TDCG exceed the normal levels. This output will cause the interpretation modules to operate so that the fault type will be identified.

TABLE V

OUTPUT OF IEEE-FILTER MODULE

\begin{tabular}{|c|c|}
\hline Code & Description \\
\hline 0 & Normal \\
\hline 1 & Abnormal \\
\hline
\end{tabular}

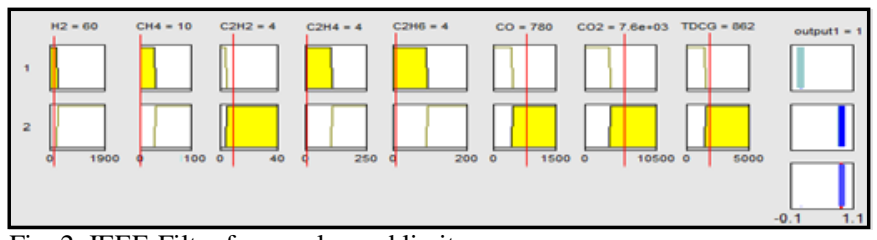

Fig. 2: IEEE-Filter fuzzy rules and limits

\section{B- Doernenburg Fuzzy logic module}

As discussed earlier, for unhealthy transformers the Doernenburg module will assess the four ratios indicated in Table II. The ratios are calculated and used as inputs for this module, a set of membership rules relating to the four input gas ratios and variable output are developed, as outlined in Table II and shown in Fig. 3, the module output codes are shown in Table VI. The four gas ratios are input to the membership function to assess against the 22 rules developed. For the tested transformer, Arc fault was determined and code "3”, Table VI is indicated, as can be seen in Fig 3.

TABLE VI

DOERNENBURG MODULE OUTPUT CODES AND FAULT TYPE

\begin{tabular}{|c|c|}
\hline Code & Fault \\
\hline 0 & Off (Module not operated) \\
\hline 1 & Thermal fault \\
\hline 2 & PD (Corona) \\
\hline 3 & Arcing fault \\
\hline 4 & Thermal or arcing \\
\hline 5 & Out of ratio \\
\hline
\end{tabular}

\begin{tabular}{|c|c|c|c|c|}
\hline $\mathrm{CH} / \mathrm{H} / \mathrm{H}=0.167$ & С2 $2 \mathrm{H} / \mathrm{C} 2 \mathrm{H} 4=1$ & $\mathrm{C} 2 \mathrm{H} 2 / \mathrm{CH}_{4}=0.4$ & С2HE/C2H2 - 1 & output1 $=3$ \\
\hline $\begin{array}{l}1 \\
2\end{array}$ & $\square$ & प्ञ & 5 & $\square$ \\
\hline${ }^{3} \begin{array}{ll} \\
\end{array}$ & 是 & प्र & 5 & 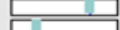 \\
\hline $19 \square$ & 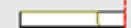 & (I) & , & -1 \\
\hline & & 4 & & \\
\hline 11 & 1 & i & & 1 \\
\hline-0 & & & & 15 \\
\hline
\end{tabular}

Fig. 3: Duval Triangle fuzzy rules and membership boundaries

\section{C- Duval Triangle fuzzy logic module}

Duval triangle is divided into 7 zones for indicating 7 types of fault and, as shown in Table VII, these provide codes for given faults. Three gas contents are calculated $\left(\mathrm{CH}_{4} \%\right.$, $\mathrm{C}_{2} \mathrm{H}_{2} \%$ and $\mathrm{C}_{2} \mathrm{H}_{4} \%$ ) and used as input to a set of fuzzy input and output memberships and rules related to the 7 divided zones: 45 rules are created for the module, as shown in Fig. 4. As discussed earlier, if the IEEE-filter module indicates normal operation then this module is not active. For the tested example, as seen in Fig. 4, the Duval module output code is "7" indicating that a Low energy discharge fault (D1) is present.

TABLE VII

DUVAL MODULE OUTPUT CODE AND FAULT

\begin{tabular}{|c|c|c|c|c|c|c|c|c|}
\hline Code & 0 & 1 & 2 & 3 & 4 & 5 & 6 & 7 \\
\hline Fault & $\begin{array}{c}\text { Off (Module not } \\
\text { Operated) }\end{array}$ & PD & T1 & T2 & T3 & DT & D2 & D1 \\
\hline
\end{tabular}

\begin{tabular}{|c|c|c|c|}
\hline \multirow[t]{2}{*}{$1{ }^{\mathrm{CH} 4-55.6}$} & $\mathrm{C}_{1} \mathrm{H} 2-22.2$ & $\mathrm{C}^{2} \mathrm{H} 4-222$ & output $=7$ \\
\hline & 亘 & 는 & प्र \\
\hline 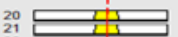 & & 든 & 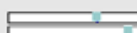 \\
\hline 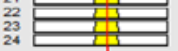 & $\frac{13}{4}$ & & 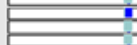 \\
\hline iं & i & ; & 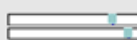 \\
\hline 100 & & & $\begin{array}{ll} & 7 \\
7 & 7 \\
\end{array}$ \\
\hline
\end{tabular}

Fig.4: Duval Triangle fuzzy logic rules and membership

\section{D- Key gas fuzzy logic model}

The Key gas method uses the relative amount of the dissolved gases to indicate the fault type. A set of input and output membership and 96 rules were developed, in cases where the module is not operated the output will be "0" "undefined". Table VIII shows the fault types and output codes. Examples of the module fuzzy logic memberships are given in Fig. 5. The module output code for the tested example is " 2 " and the Key gas interpretation is a Thermal-cellulose fault.

TABLE VIII

KEY GAS MODULE OUTPUT CODES AND FAULT

\begin{tabular}{|c|c|c|c|c|c|}
\hline Code & 0 & 1 & 2 & 3 & 4 \\
\hline Fault & Undefined & $\begin{array}{c}\text { Thermal } \\
\text { Fault in } \\
\text { oil }\end{array}$ & $\begin{array}{c}\text { Thermal- } \\
\text { cellulose } \\
\text { fault }\end{array}$ & $\begin{array}{c}\text { Partial } \\
\text { discharge } \\
\text { fault }\end{array}$ & Arcing Fault \\
\hline
\end{tabular}

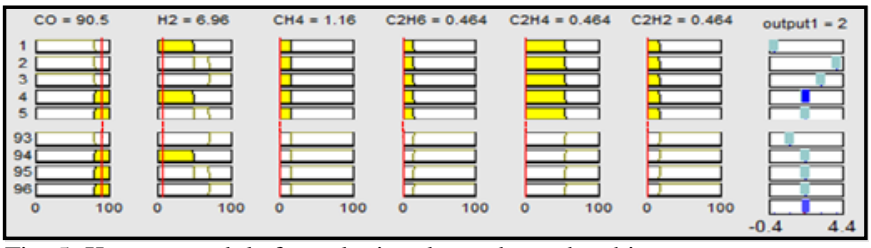

Fig. 5: Key gas module fuzzy logic rules and membership

\section{E- Combination fuzzy logic module}

In the first step of the model, the transformer health was tested using IEEE-Filter module and the transformer was classified as faulty and assessment is required in order to determine the fault type. Duval, Doernenburg and Key gas modules operate individually using different input gases: Doernenburg and Duval modules indicate Arcing and D1 faults respectively, however, Key gas module indicates a 
thermal-cellulose fault. The combination module proposed uses the output of the previous modules as inputs to the combination module. The individual fuzzy logic modules for the various DGA interpretation techniques are integrated into a single aggregated model, as shown in Fig. 6. The input and output membership functions have been fuzzified based on the variable output codes of the IEE-Filter, Duval, Doernenburg and Key gas modules.

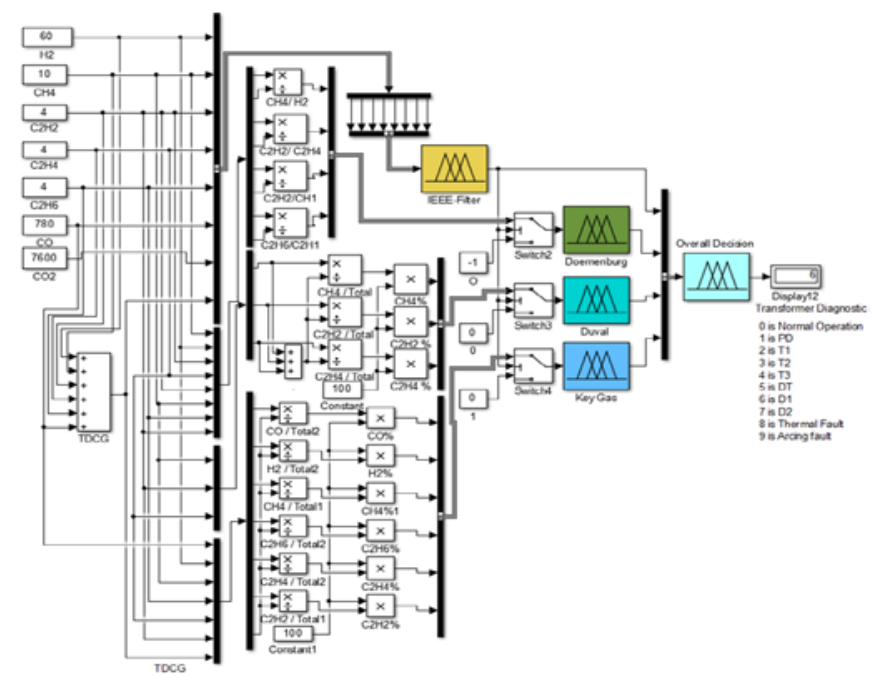

Fig.6: Overall fuzzy logic model

For the example transformer the four input codes are shown in Table IX, a set of 177 rules has been constructed to provide one output indicating the health of the transformer and fault type, using variable codes. Fig. 7 shows examples of the developed rules and memberships for the combination module. Table X shows the module's output codes. For the tested transformer, as seen from Fig. 7, the output code of the combination module is " 6 ", indicating a "D1" low energy discharge fault, which is in line with the reported fault.

TABLE IX

KEY GAS MODULE OUTPUT CODES AND FAULT

\begin{tabular}{|c|c|c|}
\hline Model & Indication & Codes \\
\hline IEEE-Filter & Abnormal & 1 \\
\hline Doernenburg ratio & Arcing Fault & 3 \\
\hline Duval triangle & D1 & 7 \\
\hline Key gas & Thermal and cellulose fault & 2 \\
\hline
\end{tabular}

TABLE $X$

COMBINATION MODULE OUTPUT CODE AND FAULT TYPE

\begin{tabular}{|c|c|c|}
\hline Code & Symbol & Fault \\
\hline 0 & NO & Pormal operation \\
\hline 1 & PD & Thermal Fault $\mathrm{T}<300^{\circ} \mathrm{C}$ \\
\hline 2 & T1 & Thermal Fault $300<\mathrm{T}<700^{\circ} \mathrm{C}$ \\
\hline 3 & T2 & Thermal Fault $\mathrm{T}>700^{\circ} \mathrm{C}$ \\
\hline 4 & T3 & Electrical and Thermal Fault \\
\hline 5 & DT & Discharge of low energy \\
\hline 6 & D1 & Discharge of high energy \\
\hline 7 & D2 & Thermal fault \\
\hline 8 & TF & Arcing fault \\
\hline 9 & AF &
\end{tabular}

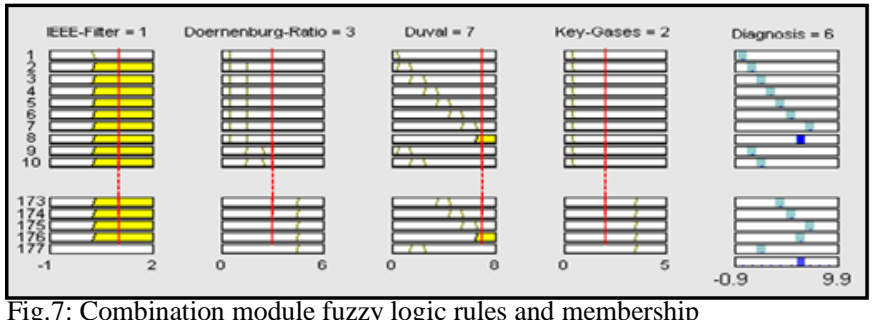

V. VALIDATION OF THE ENHANCED MODEL

As indicated earlier, data from 444 DGA samples for which faults are known were collected from published research, the papers used were [13], [14], [21]-[45].

\section{A- Transformer health classification}

The assessment of transformer health has been checked using the concentration limits of the 7-key gases and TDCG. For the 444 DGA samples investigated, the module has 99.10 $\%$ accuracy, i.e. only 4 samples out of 444 tested samples do not match the reported indication in the source document. Table XI shows the number of DGA samples that are classified as being from healthy and unhealthy transformers and the match to the reported faults.

TABLE XI

THE FILTERING MODULE'S ACCURACY AND HEALTH CLASSIFICATION

\begin{tabular}{|c|c|c|c|c|}
\hline & \multicolumn{2}{|c|}{ Accuracy } & \multicolumn{2}{c|}{ Health classification } \\
\hline Total & Disagreed & Agreed & Healthy & Un-healthy \\
\hline 444 & 4 & 440 & \multirow{2}{*}{37} & 403 \\
\hline $100 \%$ & $0.90 \%$ & $99.10 \%$ & & 403 \\
\hline
\end{tabular}

A- Application of the three interpretation techniques to indicate the fault type

As indicated earlier, abnormal cases are investigated, using the techniques discussed, to identify the nature of the fault: finally an overall decision is given on the fault type. The interpretation modules are applied to only 403 samples, then the outputs of the three techniques are combined to provide an overall decision. Table XII demonstrates the accuracy of each technique and the overall decision of the model. It is clear that Duval is more accurate than Doernenburg and Key gases. In addition, it can be seen that the overall accuracy has been improved by applying the combination rules in the developed model, reaching $99 \%$ as compared to $97 \%$ with the highest of the individual techniques.

TABLE XII

ACCURACY OF INDIVIDUAL TECHNIQUES AND OVERALL DECISION

\begin{tabular}{|c|c|c|c|c|c|c|c|c|c|c|c|c|}
\hline $\begin{array}{c}\text { Known } \\
\text { Fault }\end{array}$ & \multicolumn{3}{|c|}{$\begin{array}{l}\text { Doernenburg } \\
\text { ratio }\end{array}$} & \multicolumn{3}{|c|}{$\begin{array}{c}\text { Duval } \\
\text { Triangle }\end{array}$} & \multicolumn{3}{|c|}{ Key gases } & \multicolumn{3}{|c|}{$\begin{array}{c}\text { Overall } \\
\text { decision }\end{array}$} \\
\hline & $\mathrm{X}$ & $\sqrt{ }$ & $\%$ & $\mathrm{X}$ & $\sqrt{ }$ & $\%$ & $\mathrm{X}$ & $\sqrt{ }$ & $\%$ & $\mathrm{X}$ & $\sqrt{ }$ & $\%$ \\
\hline 403 & ฑ & W్心 & 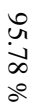 & $\vec{A}$ & $\begin{array}{l}\text { W } \\
0 \\
0\end{array}$ & $\begin{array}{l}\text { \% } \\
\text { N } \\
\text { o̊ }\end{array}$ & जै & $\underset{\infty}{N}$ & $\begin{array}{l}\underbrace{\infty} \\
\underbrace{}_{0} \\
\underbrace{\circ}\end{array}$ & ט & $\underset{\infty}{\infty}$ & 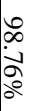 \\
\hline
\end{tabular}

The outputs of the three techniques which are the inputs to the combination model have been studied and used to generate a set of fuzzy rules for improving the accuracy of the overall decision of the system. Table XIII shows all possible 
cases of agreement and disagreement within the individual techniques after they have been compared to the recorded fault. A $\sqrt{ }$ agreement with the reported fault, a $\mathrm{X}$ indicates disagreement with the reported fault. As shown in Table XIII, when the three techniques all identify the same fault there is very low chance that the three techniques incorrectly predict the fault. Also, it is clear that when two approaches are in agreement $(21.85 \%)$, their prediction of the fault is the right answer. For the sake of clarity when the actual fault is thermal fault or arcing fault, Duval's indication is DT. Therefore, in cases where the three techniques agree, the output of the combination system will consider that is the correct indication. In cases where only two techniques agree, the combination system will consider the agreed two as the correct indication, when all three disagree the overall decision will consider Duval's indication.

TABLE XIII

AGREEMENT PERCENTAGES OF THE APPLIED FOR REPORTED FAULTS

\begin{tabular}{|c|c|c|c|c|}
\hline Duval & Doernenburg & Key Gases & $\begin{array}{c}\text { Number of } \\
\text { Sample }\end{array}$ & Percentage \\
\hline$\sqrt{ }$ & $\sqrt{ }$ & $\sqrt{ }$ & 307 & $76.18 \%$ \\
\hline$\sqrt{ }$ & $\sqrt{ }$ & $\mathrm{X}$ & 70 & $17.37 \%$ \\
\hline $\mathrm{X}$ & $\sqrt{ }$ & $\sqrt{ }$ & 9 & $2.24 \%$ \\
\hline$\sqrt{ }$ & $\mathrm{X}$ & $\sqrt{ }$ & 9 & $2.24 \%$ \\
\hline $\mathrm{X}$ & $\sqrt{ }$ & $\mathrm{X}$ & 0 & $0 \%$ \\
\hline$\sqrt{X}$ & $\mathrm{X}$ & $\mathrm{X}$ & 3 & $0.74 \%$ \\
\hline $\mathrm{X}$ & $\mathrm{X}$ & $\sqrt{ }$ & 3 & $0.74 \%$ \\
\hline \multicolumn{5}{r}{} \\
\hline
\end{tabular}

\section{$B$ - Discussion for the model's results}

Table XIV shows 10 cases out of 444 DGA tested samples to show the model's operation. Table XV shows the IEEEFilter classification for the 10 cases, the assessment of the interpretation techniques and the overall decision of the model. For example 1 from Table XIV, the concentration of the 7-key gases and TDCG are below the specified levels in [16] (see Table I), therefore the IEEE-Filter indicates that this sample is " 0 " for Normal Operation and no further investigation is required. Therefore, the Doernenburg, Duval and key gas models will not operate, and their output codes are "zeros", as shown in Tables VI, VII and VIII, respectively. In such case, the overall decision of the model will consider the outcome of the IEEE-Filter only indicating Normal Operation (NO), using the code (0) as demonstrated in Table X. For example 2, $\mathrm{C}_{2} \mathrm{H}_{2}$ is " 2 " ppm and this concentration is exceeding its normality, in this instance the indication of IEEE-Filter is Abnormal (1) even though, in the reported diagnosis this sample is from a healthy transformer. It should be noted that $\mathrm{CO}$ and $\mathrm{CO}_{2}$ are Not Given N-G in the source and value of 0.001 is applied to the model. The three techniques are operated and fault type is diagnosed, however, this case is noted as being in-correct indication and that has affected the IEEE-Filter accuracy. In case 3, the three techniques agree and are in line with the reported fault. In case 4, Doernenburg and Key gas indicate Thermal and Arcing fault, respectively, Duval indicates that both types of fault are occurring (DT), therefore, the combination system judgment will consider Duval's indication. Examples 5-9 show the cases when two techniques agree and shows the overall decision considered the agreed two. In case 10, all techniques diagnose a Thermal fault and the overall decision considered this result, however, the reported fault is Arcing.

TABLE XIV

SECTION OF CASES OF THE VALIDATION PROCESS

\begin{tabular}{|c|c|c|c|c|c|c|c|c|}
\hline z & $\underset{N}{\mathbb{N}}$ & $\stackrel{\Omega}{I}$ & $\underset{N}{N}$ & $\underset{\mathbb{N}}{\stackrel{0}{\mid c}}$ & 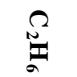 & ๑ & O & $\begin{array}{l}\pi \\
\mathbb{2}\end{array}$ \\
\hline 1 & 10 & 1 & 0 & 0 & 1 & 176 & 0 & [24] \\
\hline 2 & 39 & 41 & 2 & 29 & 16 & $\mathrm{~N}-\mathrm{G}$ & $\mathrm{N}-\mathrm{G}$ & [22] \\
\hline 3 & 10 & 24 & 0.01 & 24 & 372 & 343 & $\mathrm{~N}-\mathrm{G}$ & [27] \\
\hline 4 & 200 & 50 & 6 & 50 & 40 & 0.01 & 0.01 & [33] \\
\hline 5 & 1790 & 580 & 619 & 336 & 321 & 956 & 4250 & [21] \\
\hline 6 & 3091 & 46 & 239 & 101 & 17 & 236 & 3305 & [46] \\
\hline 7 & 530 & 345 & 250 & 266 & 85 & 3900 & 20000 & [31] \\
\hline 8 & 48 & 610 & 0 & 10 & 29 & 1900 & 970 & [21] \\
\hline 9 & 36036 & 4704 & 10 & 5 & 554 & 6 & 347 & [21] \\
\hline 10 & 9817 & 36926 & 213 & 62815 & 11608 & 837 & 6649 & [39] \\
\hline
\end{tabular}

TABLE XV

THE MODEL OUTPUT FOR THE TESTED DGA SAMPLES

\begin{tabular}{|c|c|c|c|c|c|c|}
\hline No & $\begin{array}{c}\text { IEEE } \\
- \\
\text { Filter }\end{array}$ & $\begin{array}{c}\text { Doernen- } \\
\text { burg }\end{array}$ & Duval & Key gas & $\begin{array}{c}\text { Overall } \\
\text { decision }\end{array}$ & Reported \\
\hline 1 & 0 & Off & Off & Undefined & Normal & Normal \\
\hline 2 & 1 & Thermal & T2 & $\begin{array}{c}\text { Thermal } \\
\text { in oil }\end{array}$ & T2 & Normal \\
\hline 3 & 1 & Thermal & T2 & $\begin{array}{c}\text { Thermal } \\
\text { in oil }\end{array}$ & T2 & MTF \\
\hline 5 & 1 & Thermal & DT & $\begin{array}{c}\text { Arcing } \\
\text { Fault }\end{array}$ & DT & $\begin{array}{c}\text { Low } \\
\text { energy } \\
\text { discharge }\end{array}$ \\
\hline 6 & 1 & Arcing & D2 & PD & D2 & $\begin{array}{c}\text { Discharge } \\
\text { of low } \\
\text { energy }\end{array}$ \\
\hline 7 & 1 & Arcing & D2 & Undefined & D2 & $\begin{array}{c}\text { Arcing } \\
\text { energy } \\
\text { Discharge }\end{array}$ \\
\hline 8 & 1 & Thermal & PD & $\begin{array}{c}\text { Thermal } \\
\text { in oil }\end{array}$ & Thermal & $\begin{array}{c}\text { Thermal } \\
<700(T 1 \\
\text { or T2) }\end{array}$ \\
\hline 9 & 1 & $\begin{array}{c}\text { Out of } \\
\text { ratio }\end{array}$ & PD & PD & PD & $\begin{array}{c}\text { Partial } \\
\text { discharge } \\
\text { (PD) }\end{array}$ \\
\hline 10 & 1 & Thermal & T3 & $\begin{array}{c}\text { Thermal } \\
\text { in oil }\end{array}$ & T3 & $\begin{array}{c}\text { Arcing } \\
\text { Fault }\end{array}$ \\
\hline
\end{tabular}

\section{CONCLUISION}

Fuzzy systems work with rules that express the imprecision and approaches of the real world. In this work, fuzzy sets are formulated for several DGA interpretation techniques and then combined to provide an improvement in accuracy of classifying transformer faults. The model accurately assigns fault type and provides an overall decision based on the Duval Triangle, Doernenburg ratio and key gas techniques.

\section{References}

[1] N. Bakar, A. Abu-Siada, and S. Islam, "A Review on Chemical Diagnosis Techniques for Transormer Paper Insulation Degradation,” in AUPEC, Sep 29-Oct3 2013. Hobart, Australia: AUPEC, pp. 1-6.

[2] S. M. Akolkar and B. E. Kushare, "Remaining Life Assessment of 
Power Transformer,” vol. 2, no. 2, pp. 45-48, 2014.

[3] M. Beykverdi, F. Faghihi, and A. Moarefian, “A New Approach for Transformer Incipient Fault Diagnosis Based on Dissolved Gas Analysis ( DGA ),” Nov. J. Eng. Appl. Sci., vol. 2, no. 3, pp. 1-7.

[4] B. J. Small and A. Abu-Siada, "A new method for analysing transformer condition using frequency response analysis," in IEEE Power and Energy Society General Meeting, 2011, pp. 1-5.

[5] C. Ciulavu and E. Helerea, "Power transformer incipient faults monitoring,” no. 32, pp. 72-77, 2008

[6] J. Fuhr and T. Aschwanden, "Experience with diagnostic tools for condition assessment of large power transformers," Electr. Insul. 2004. Conf. Rec. IEEE Int. Symp., no. September, pp. 508-511, 2004.

[7] N. . Muhamad, B. . Phung, and T. . Blackburn, "Comparative Study and Analysis of DGA Methods for Mineral oil using Fuzzy Logic," IEEE Power Eng. Conf. 2007, pp. 1301-1306, 2007.

[8] M. Balasubramanian, G. Ravi, Dharmalingam, and V. Dharmalingam, "Interdependence of Thermal and Electrical Stresses on Initiating Degradation of Transformer insulation preformances," IEEEInternational Conf. Adv. Eng. Sci. Manag., pp. 399-402, 2012.

[9] I. Metwally, "Failures, Monitoring and New Trends of Power Transformers,” IEEE Potentials, vol. 30, no. 3, pp. 36-43, 2011.

[10] N. Barle, R. Sarojinee, and M. K. Jha, "Dissolved Gas Analysis of Power Transformer using AUROCC-based Genetic Fuzzy SVM Fusion model,” Int. J. Innov. Res. Sci. Eng. Technol., vol. 04, no. 01, pp. 18858-18871, 2015.

[11] A. Suleiman and A. Alghamdi, "Improving accuracy of DGA interpretation of oil-filled power transformers needed for effective condition monitoring," 21st Med.Conf.ControlAutom., pp.584-589.

[12] A. D. Ashkezari, T. K. Saha, C. Ekanayake, and H. Ma, "Evaluating the accuracy of different DGA techniques for improving the transformer oil quality interpretation,” 2011 21st Australas. Univ. Power Eng. Conf. AUPEC 2011, pp. 1-6, 2011.

[13] A. Abu-Siada, S. Hmood, and S. Islam, "A new fuzzy logic approach for consistent interpretation of dissolved gas-in-oil analysis,” IEEE Trans. Diel. Electr. Insul., vol. 20, no. 6, pp. 2343-2349, Dec. 2013.

[14] L. Bouchaoui, K. E. Hemsas, and S. Benlahneche, "DGA Results Comparison between ANN Methods and Tested Sampling from Sonelgaz-GRTE Transformers Fleet," Transm. Chief Eng. - SonelgazGRTE - SETIF. www.univ-sba.dz/iceps/icen10/frames/Articles/IV/IV

[15] E. Lee and W. Meng, "Dissolved Gas Analysis ( DGA ) of mineral oil used in transformers,” no. May, pp. 4-5, 2009.

[16] "IEEE Std C57.104-2008 - IEEE Guide for the Interpretation of Gases Generated in oil-Immersed Transformer," IEEE Power Energy Soc. Spons. by Transform. Comm., no. 2, pp. 1-36, 2009.

[17] S. Ghoneim and K. A. Shoush, "Diagnostic Tool for Transforme Fault Detection Based on Dissolved Gas Analysis,” IOSR J. Electr. Electron. Eng. www.iosrjournals.org, vol. 9, no. 5, pp. 20-26, 2014

[18] S. Singh and M. N. Bandyopadh, "Duval Triangle: A Noble Technique for DGA in Power Transformers,” International Journal of Electrical and Power Engineering, vol. 4, no. 3. pp. 193-197, 2010.

[19] A. S. A. and A. A. . and M. N. A. and bASHIR. N. and Aizam.Mohd, "Improving accuracy of DGA interpreation of oil-filled power transformers needed for effective condition monitoring," in IEEE Int'l on Condition Monitoring and Diagnosis, September, pp. 374-378.

[20] N. Sharma, S. Piplikhera, and S. Email, "Power Transformer Diagnosis Using Fuzzy Logic,” vol. 1, no. 2, pp. 149-151, 2012.

[21] M. Duval and A. DePablo, "Interpretation of gas-in-oil analysis using new IEC publication 60599 and IEC TC 10 databases,” IEEE Electr. Insul. Mag., vol. 17, no. 2, pp. 31-41, 2001.

[22] D. R. Morais, J. R. d. Silva, and J. G. Rolim, “A Fuzzy System for Detection of Incipient Faults in Transformers based on the Dissolved Gas Analysis of Insulating Oil,” Diagnostics Elect. Mce. Power Elect. Drives, 5th IEEE Int. Sym. SDEMPED, vol. 21, no. 2, pp. 1-6, 2005.

[23] M. Beykverdi, F. Faghihi, and A. Moarefian, "A New Approach for Transformer Incipient Fault Diagnosis Based on Dissolved Gas Analysis ( DGA ),” Nov. J. Eng. Appl. Sci., vol.2, March, 2014, p. 1-7.

[24] H. Ahadpour, "A Novel Approach for Diagnosis of Power Transformers Internal Faults Using an Electronic Nose,” J. Basic Appl. Sci. Res., vol. 1, no. 7, pp. 808-815, 2011.

[25] R. A. Hooshmand, M. Parastegari, and Z. Forghani, "Adaptive NeuroFuzzy Inference System Approach for Simultaneous Diagnosis of the
Type and Location of Faults,” IEEE Elect. Ins. Mag., pp. 32-42, 2012.

[26] D. V. S. S. Sarma and G. N. S. Kalyani, "ANN Approach for Condition Monitoring of Power Transformers Using DGA,” TENCON 2004. 2004 IEEE Reg. 10 Conf., vol. 100, pp. 444-447, 2004.

[27] S. S. M. Ghoneim, I. B. Taha, “Artificial Neural Networks for Power Transformers Fault Diagnosis Based on IEC Code Using Dissolved Gas Analysis,” Int. J. Control. Autom. Syst., vol. 4, no. 2, pp. 18-21, 2015

[28] N. Yadaiah and N. Ravi, "Development of Dissolved Gas Analysis Using ANFIS,” IInternational J. Recent Trends Eng. Technol. ACEEE, vol. 11, no. 1, pp. 120-129, 2014.

[29] C. P. Hung and M. H. Wang, "Diagnosis of incipient faults in power transformers using CMAC neural network approach,” Electr. Power Syst. Res., vol. 71, no. 3, pp. 235-244, 2004.

[30] S. Ghoneim and K. A. Shoush, "Diagnostic Tool for Transformer Fault Detection Based on Dissolved Gas Analysis,” IOSR J. Electr. Electron. Eng., vol. 9, no. 5, pp. 20-26, 2014.

[31] Sadeq Yasoob Jasim \& Jyoti Shrivastava, "Dissolved Gas Analysis of Power Transformers,” Int. J. Electr. Electron. Eng. Res. JEEER, vol. 3, no. 5, pp. 1-10, 2013.

[32] H. Nabwey, E. Rady, A. Kozae, and A. Ebady, "Fault Diagnosis of Power Transformer Based on Fuzzy Logic Rough Set theory and Inclusion Degree Theory,” J. Power Energy Eng., vol. 1, no. 2, pp. 45-49, 2008.

[33] T. Zhang, J. Lu, G. Zhang, and Q. Ding, "Fault diagnosis of transformer using association rule mining and knowledge base," 10th IEEE nternational Conf. Intell. Syst. Des. Appl., pp. 737-742, 2010.

[34] A. Akbari, A. Setayeshmehr, H. Borsi, E. Gockenbach, and I. Fofana, "Intelligent agent-based system using dissolved gas analysis to detect incipient faults in power transformers,” Elect. Insul. Mag. IEEE, vol. 26, no. 6, pp. 27-40, 2010.

[35] H. V Waghmare and P. H. H. Kulkarni, "Modeling of Transformer DGA using IEC \& Fuzzy Based Three Gas Ratio Method,” Int. J. Eng. Res. Technol. IJERT, vol. 3, no. 9, pp. 1149-1152, 2014.

[36] H. Ikbal and S. R. Farag, "Monitoring Power Transformer Using Fuzzy Logic,” J. Eng. Dev., vol. 17, no. 6, pp. 146-163, 2013.

[37] K. Tomsovic and A. Amar, "On Refining Equipment Condition Monitoring using Fuzzy Sets and Arti cial Neural Nets,” Ingineering Intell. Syst. Electr. Eng. Commun., vol. 5, pp. 1-19, 1997.

[38] S. Seifeddine, B. Khmais, and C. Abdelkader, "Power transformer fault diagnosis based on dissolved gas analysis by artificial neural network," $1^{\text {st }}$ IEEE Int. Conf. Renew. Energies Veh. Tech., pp. 230236, 2012.

[39] M.Horning, J.Kelly, S.Myers, and R.Stebbins, "Transformer Maintenance Guide,” Copyr. book. Third Ed. 0-939320-02-9, 2004.

[40] S. S. Ghoneim and S. A. Ward, "Dissolved Gas Analysis as a Diagnostic Tools for Early Detection of Transformer Faults," Adv. Electr. Eng. Syst. (AEES), Vol. 1, no. 3, pp. 152-156, 2012.

[41] A. Nunez, "Transformer On-line monitoring," www.mistrasgroup.com/services/company/publications/Fault_Detectio n_Online_Monitoring.pdf, no. October2006, pp. 1-15, 2006.

[42] U. Roland and O. Eseosa, "Artificial Neural Network Approach to Distribution Transformers Maintenance,” Int. J. Sci. Res. Eng. Technol., vol. 1, no. 4, pp. 62-70, 2015.

[43] S. G. Gaikwad, P. S. Swami, and A. G. Thosar, "Comparison of Conventional and Fuzzy Logic Approach for DGA of EHV Transformer,” Int'l J. Recent Tech. Eng., vol. 4, no. 5, pp.30-37, 2015.

[44] K. Jane, P. S. A. Borakhade, "Dissolved Gas Analysis in Transformer using Three Gas Ratio Method and Fuzzy Logic based on IEC Standard,” SSRG Int. J. Electr. Electron. Eng. SSRG-IJEEE, vol. 2, no. 4, pp. 1-4, 2015.

[45] R. N. Afiqah, I. Musirin, D. Johari, M. M. Othman, T. K. . Rahnan, and Z. Othman, "Fuzzy Logic Application in DGA Methods to Classify Fault Type in Power Transformer,” Selected.Topics Power Syst. Remote Sensing., ISSN: 1792-5088, pp. 83-88, 2009.

[46] R. A. Hooshmand, M. Parastegari, and Z. Forghani, “Adaptive NeuroFuzzy Inference System Approach for Simultaneous Diagnosis of the Type and Location of Faults in Power Transformers," IEEE Elect. Insul. Mag., vol. 28, no. 5, pp. 32-42, 2012. 